\title{
Stability Study of Ipomoea reptans Extract Self-Nanoemulsifying Drug Delivery System (SNEDDS) as Anti-Diabetic Therapy
}

\author{
Pinus Jumaryatno ${ }^{1 *}$, Lutfi Chabib ${ }^{1,2}$, Farida Hayati ${ }^{1}$, Rizki Awaluddin ${ }^{1}$ \\ ${ }^{1}$ Department of Pharmacy, Islamic University of Indonesia, Yogyakarta, Indonesia. \\ ${ }^{2}$ Faculty of Pharmacy, Gadjah Mada University, Yogyakarta, Indonesia.
}

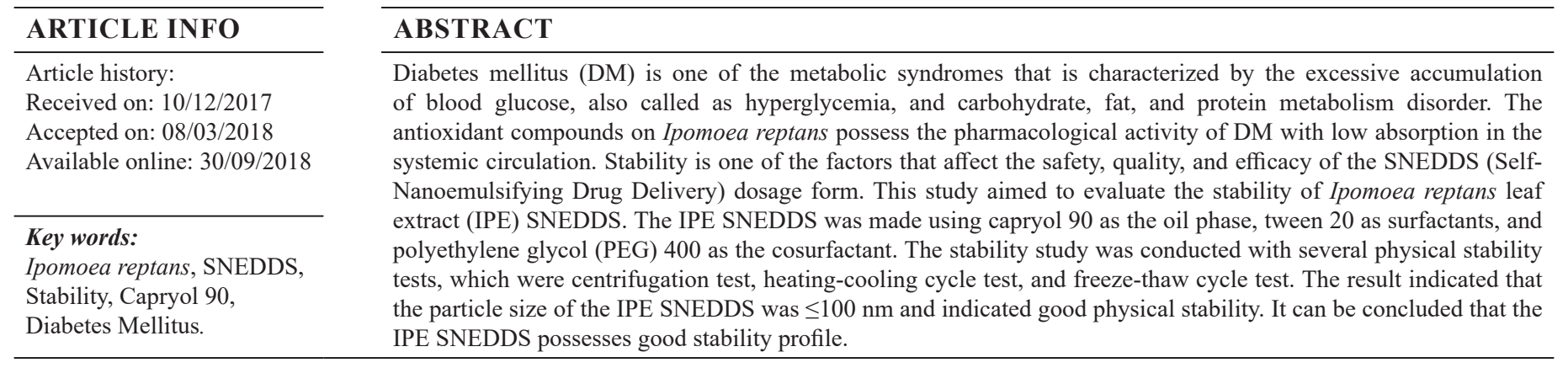

\section{INTRODUCTION}

Diabetes mellitus as the third most deadly health problem in the world can lead to complications that worsen the body organs condition such as chronic hyperglycemia, long-term damages, dysfunctions, and organ failures (Sucharitha and Estari, 2013). Free radicals are considered as one of the causes of several degenerative diseases such as hepatic cirrhosis, atherosclerosis, cancer, and diabetes mellitus (Uttara et al., 2009). The activity of free radicals can initiate the lipid peroxidation, which stimulates the protein glycation, enzyme inactivation and generates longterm complication of diabetes (Lyons and Jenkins, 1997).

Antioxidants play a role to keep the body from the invasion of reactive oxygen species (Sabu and Kuttan, 2002). It has been reported that Asia and Africa have $56 \%$ of the medicinal plants spreading in the world. The contained pharmacological activities are related to the contents of chemical compounds such as phenolic, alkaloids, flavonoids, terpenoids, coumarin, and

"Corresponding Author

Pinus Jumaryatno, Department of Pharmacy, Faculty of Mathematics and Natural Sciences, Islamic University of Indonesia, Yogyakarta. E-mail: pinus.jumaryatno@uii.ac.id glycosides that produce positive effects (Mamun-or-rashid et al., 2014).

In the previous study, the Ipomoea reptans leaf extract indicated the pancreatic protector activity in the streptozotocininduced mice, which makes it considered to contains antioxidant compounds, which are $\beta$-carotene, riboflavin, vitamin $\mathrm{A}$, tocopherol, 3-methoxy quercetin, 4-methoxy quercetin polyphenol, and anthocyanin (Hayati et al., 2017; Manvar and Desai, 2013). In addition, Ipomoea reptans leaf extract has been shown to lower blood glucose level of mice with the dose of $2.23 \mathrm{~g} / \mathrm{kgBW}, 4.46 \mathrm{~g} /$ $\mathrm{kgBW}$, and $8.92 \mathrm{~g} / \mathrm{kgBW}$. However, a modification of the carrier preparation is required to improve the bioavailability of the extract (Hayati et al., 2010).

Self-nano Emulsifying Drug Delivery System (SNEDDS) is a dosage form that can improve the bioavailability of lipophilic compounds that lead to an improvement of its clinical efficacy, simplify permeability of drugs, and lower the dose needed to generate clinical effects (Makadia et al., 2013; Jain et al., 2010). The stability of SNEDDS depends on the size of globules in the dispersed phase of SNEDDS. Small globules could improve the stability of SNEDDS by lowering the gravity and the Brownian motion that prevent the occurrence of creaming 
and flocculation (Chabib et al., 2017). In this study, the stability of the IPE SNEDDS was observed by conducting centrifugation test, heating-cooling cycle test, freeze-thaw cycle test that aims to review the physical stability and to obtain the stable IPE SNEDDS formula.

\section{MATERIALS AND METHODS}

\section{Materials}

The materials used were Ipomoea reptans leaf extract (obtained from Laboratorium Biologi Farmasi UII), aqua pro injection, tween 20 (Vivantis Inc.), polyethylene glycol 400 (Brataco), and capryol 90 (Gattefose).

\section{Methods}

\section{Extraction of Ipomoea reptans leaf}

Post-harvest treatments were sorting (leaf only), drying at $45^{\circ} \mathrm{C}-50^{\circ} \mathrm{C}$ for $2-3$ days, and powdered using a grinder. Ipomoea reptans leaf powder was extracted by maceration for 6 days using $96 \%$ ethanol (ratio 1:10), and remaceration for 6 days with the same solvent. The viscous extract was obtained by evaporating the solvent using a rotary evaporator with a temperature of $60^{\circ} \mathrm{C}$ (Hayati et al., 2015).

\section{Formulation of the Ipomoea reptans leaf extract (IPE) SNEDDS}

The formula of IPE SNEDDS was modified from Chabib, who conducted the previous study (Chabib et al., 2017). The formula was presented in table 1 .

Table 1: IPE SNEDDS formula.

\begin{tabular}{ccc}
\hline Material & Function & Quantity \\
\hline IPE & Active Ingredients & $500 \mathrm{mg}$ \\
Capryol 90 & Oil phase & $0.5 \mathrm{~mL}$ \\
Tween 20 & Surfactant & $3.5 \mathrm{~mL}$ \\
PEG 400 & Co-surfactant & $1 \mathrm{~mL}$ \\
\hline
\end{tabular}

The Ipomoea reptans leaf extract was weighed carefully, then it was dissolved into the oil phase (Capryol 90) until it was dissolved completely. The solution then was gradually added with the surfactant and co-surfactant and was ultrasonicated (Model 300 VT Biologics, Inc) for 2 minutes 4-7 times.

\section{Centrifugation test}

The IPE SNEDDS was diluted 100 times with aqua pro injection. Then, it was centrifugated using the centrifugator (Hanil MF 80) with speed of $3500 \mathrm{rpm}$ for 30 minutes. Then, the phase separation was observed visually, the presence of phase separation indicates a difference in kinetic stability in nanoemulsion resulting in emulsion system instability, such as creaming, flocculation, cracking or coalescence (Shukla and Patel, 2010).

\section{Heating-Cooling cycle test}

The formula resulted from the centrifugation test was used in the heating-cooling cycle test. The test was conducted with six cycles at the temperature of $4^{\circ} \mathrm{C}$ and $40^{\circ} \mathrm{C}$ and stored for not less than 48 hours using Climatic Chamber (Climacell). The temperature of the stored formula was stabilized and centrifugated with speed of $3500 \mathrm{rpm}$ for 15 minutes and observed visually to check the phase separation (Gupta et al., 2011).

\section{Freeze-thaw cycle test}

The formula resulted from the heating-cooling cycle test was used in the freeze-thaw cycle test. The test was conducted with six cycles at the temperature of $-20^{\circ} \mathrm{C}$ and $25^{\circ} \mathrm{C}$ and stored for not less than 48 hours using Climatic Chamber (Climacell). The formula was stabilized at normal temperature and centrifugated with speed of $3500 \mathrm{rpm}$ for 15 minutes and observed visually to check the phase separation (Gupta et al., 2011).

\section{Endurance test}

The formula resulted from the freeze-thaw cycle test was used to conduct the endurance test. The formula was diluted with dilutions of 25,50 , and 100 times with aqua pro injection. Then, the change of \%transmittance, polydispersity index (PDI), and particle size of the formula were evaluated using Particle Size Analyzer (Horiba Sz 100) (Gupta et al., 2011).

\section{RESULT AND DISCUSSION}

\section{IPE SNEEDS}

Ipomoea reptans leaf extract (IPE) has characteristics of concentrated extract, greenish color (Hayati et al., 2015). The SNEDDS formulation with the material ratio as table 1 consists of extract, oil phase, and surfactant. IPE SNEEDS exhibits dark color due to the formation of colloidal dispersion as in Figure 1. However, IPE SNEEDS forms an oil-in-water nanoemulsion (nanodroplet) when interacting with an aqueous medium (e.g. gastrointestinal fluid) that change the color into clear or cloudy as in Figure 2 tested durability by the effect of dilution (Yen et al., 2017).

\section{Centrifugation test}

The centrifugation test is conducted to assess the SNEDDS stability after an emulsion is formed, against the gravity force. The result of centrifugation that was shown in table 2 indicated that no phase separation occurred during the test.

Table 2: The result of the IPE SNEDDS stability test.

\begin{tabular}{cccc}
\hline Replication & Centrifugation & Heat-Cool Cycle & Freeze-Thaw Cycle \\
\hline 1 & No phase separation & No phase separation & No phase separation \\
2 & No phase separation & No phase separation & No phase separation \\
3 & No phase separation & No phase separation & No phase separation \\
\hline
\end{tabular}

Centrifugation describes the gravity force that occurs on the droplets. The small size of droplets can minimize the gravity force and Brownian motion on the particles that prevent the occurrence of phase separation (Fanun, 2012).

\section{Heating-cooling and freeze-thaw test}

Freeze-thaw cycle test is conducted to examine the effect of heating, cooling, and centrifugation against the stability of SNEDDS formula (Patel et al., 2008). An emulsion tends 
to be stable at the temperature of $40^{\circ} \mathrm{C}-45^{\circ} \mathrm{C}$ in few hours of storage. Heating and freezing are potential to damage or break the droplets of an emulsion (Anton and Thierry, 2011). Table 2 indicates that there was no phase separation occurred in the SNEDDS formula during the heating-cooling cycle and freezethaw cycle test.

\section{Endurance test}

The test is conducted to observe the character similarity of the nanoemulsion through various level of dilutions. The test is also can be used to ensure that the drug would not form a sedimentation. The result of the endurance test was shown in figure 2 and table 3.

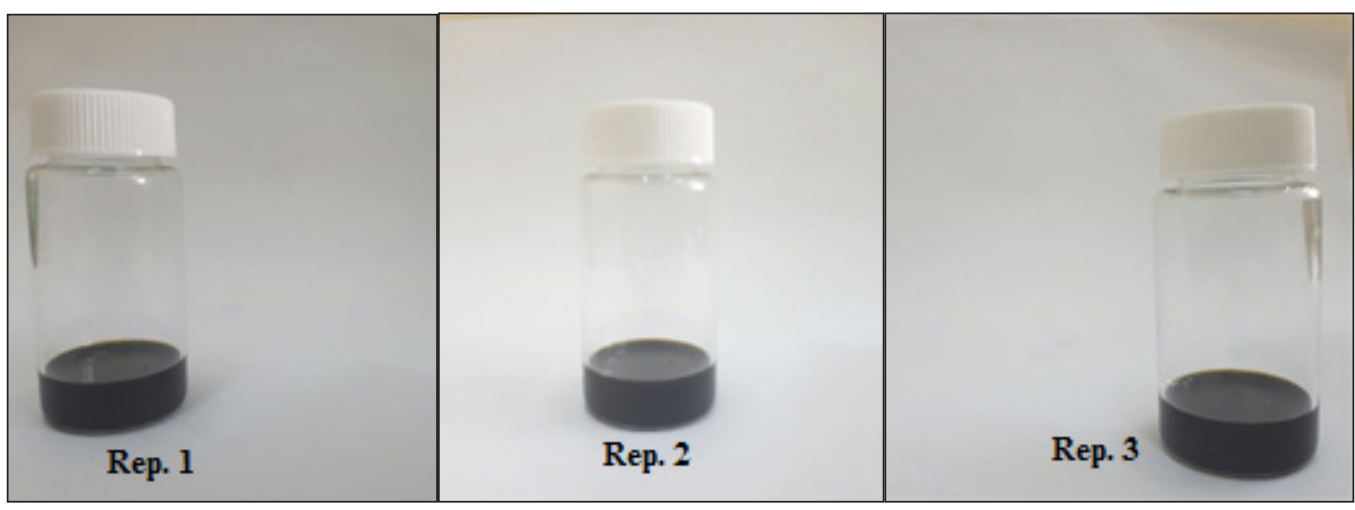

Fig. 1: IPE SNEDDS.

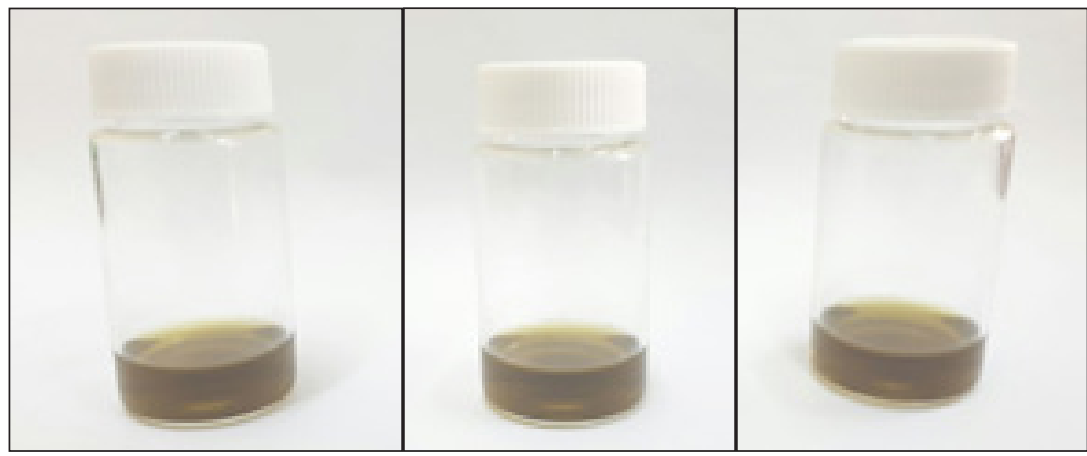

Fig. 2: The result of the endurance test with slightly greenish color.

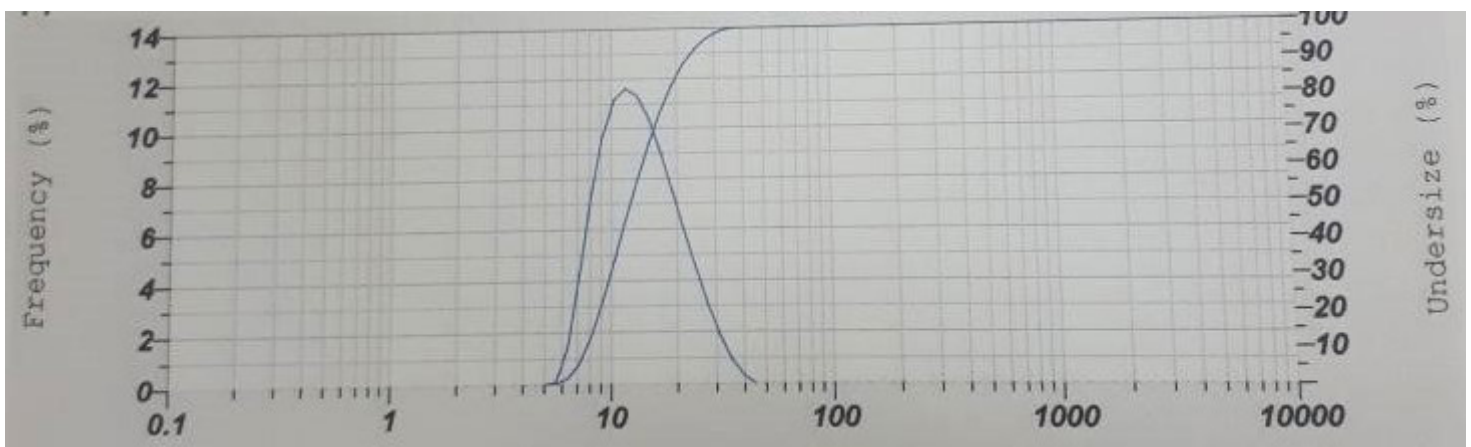

Fig. 3: Particle size analysis of IPE SNEEDS (one of the samples).

Based on the test using particle size analyzer, the particle size of the IPE SNEDDS formula was $(15.5 \pm 0.8 \mathrm{~nm})$ and the PDI was $0.558 \pm 0.04$. Nanoemulsion is characterized by the particle size 0.1-100 nm with narrow particle size distribution and the particle size is still stable through dilutions (Dolati et al., 2016; Shah et al., 2010; Rao and Shao, 2008). In addition, the small particle size of the nanoemulsion will increase the permeability of absorption, that lead to an improvement of the oral bioavailability of compounds (Yen et al., 2017).

Whereas, the PDI values from the study were between
$0.2-0.7$. The PDI value above 0.40 indicates wider particle size distribution and lower particle size uniformity (Chabib et al., 2017; Mao et al., 2009). Phase conversion of the dosage form can be considered as one of the kinetic and thermodynamic parameters in an optimal formula selection (Makadia et al., 2013).

\section{CONCLUSION}

The IPE SNEDDS possesses good stability that is proven with no phase separation occurs during several tests such as centrifugation, heating-cooling cycle, and freeze-thaw cycle. The 
particle size and PDI value obtained in the study indicated that the IPE SNEDDS possesses optimal characteristic as a nanoemulsion.

Table 3: The result of the endurance test.

\begin{tabular}{ccc}
\hline Dilution & Particle size $(\mathbf{n m})$ & PDI \\
\hline $25 \mathrm{x}$ & 14.6 & 0.581 \\
$50 \mathrm{x}$ & 15.5 & 0.586 \\
$100 \mathrm{x}$ & 16.3 & 0.507 \\
Average $\pm \mathrm{SD}$ & $15.5 \pm 0.8$ & $0.558 \pm 0.04$ \\
\hline
\end{tabular}

\section{ACKNOWLEDGMENT}

This study was sponsored by Ministry of Research, Technology and Higher Education of The Republic of Indonesia under scheme Penelitian Terapan Unggulan Perguruan Tinggi 2017 (No. 032/ST-DirDPPM/70/DPPM/Penelitian Terapan Unggulan Perguruan Tinggi-KEMENRISTEKDIKTI/IV/2017) granted to F.H. The authors also would like to thank Department of Pharmacy Islamic University of Indonesia for the facilities.

\section{REFERENCES}

Anton N, Thierry V. Nano-emulsions and Micro-emulsions: Clarifications of the Critical Differences. Pharm. Res. 2011; 28:978-985.

Chabib L, Muhtadi WK, Ikawati Z, Martien R, Ismail H. Stability Study of Gamavuton (Gvt-0) Self-Nanoemulsifying Drug Delivery System (Snedds) with Myritol as The Oil Phase. Int. J. Curr. Inov. Res. 2017; 3:590-594.

Dolati S, Sadreddini S, Rostamzadeh D, Ahmadi M, ScienceDirect Utilization of nanoparticle technology in rheumatoid arthritis treatment. Biomed. Pharmacother. 2016; 80:30-41.

Gupta S, Chavhan S, Sawant KK. Self-Nanoemulsifying Drug Delivery System for Adefovir Dipivoxil: Design, Characterization, In Vitro and Ex Vivo Evaluation. Colloids Surf A Physicochem Eng Asp. 2011; 392:145-155.

Fanun M, Microemulsions as Delivery Systems. Curr. Opin. Colloid Interface Sci. 2012; 17:166-172.

Hayati F, Lulung W, Marsih L. The Effect Of Ipomoea reptans Poir Ethanolic Extract On The Histopathological Parameters Of Pancreas In Streptozotocin-Induced Diabetic Rats. Int. Conf. Chem. Chem. Process Eng. 2017; 20046.

Hayati F, Wibowo A, Jumaryatno P, Nugraha AT. Standardization of the Extract of Cultivated Ipomoea reptans Poir. Leaves from Sardonoharjo, Sleman and Its Potency as Antioxidant). J. Ilmu Kefarmasian Indones. 2015; 13.

Hayati F, Windyarini S, Helminawati. Efek Antihiperglikemik Infusa Kangkung Darat (Ipomoea reptans Poir) pada mencit jantan galur Swiss yang diinduksi Streptozotocin. J. Ilm. Farm. 2010; 7:13-22.
Jain N, Jain R, Thakur N, Gupta BP, Jain DK, Jain S. Nanotechnology: A Safe And Effective Drug Delivery System. Asian J. Pharm. Clin. Res. 2010; 3:159-165.

Lyons TJ, Jenkins AJ. Glycation, oxidation, and lipoxidation in the development of the complications of diabetes: a carbonyl stress hypothesis. Diabetes Rev (Alex), 1997; 5:365-391.

Makadia MHA, Bhatt MAY, Parmar RB, Paun MJS, Tank HM Self-nano Emulsifying Drug Delivery System (SNEDDS): Future Aspects. Asian J. Pharm. Res. 2013; 3:21-27.

Mamun-or-Rashid ANM, Hossain S, Hassan N, Dash K, Sapon A, Sen MK. A review on medicinal plants with antidiabetic activity. 2014; 3:149-159.

Manvar M, Desai T. Phytochemical and Pharmacological Profile of Ipomoea Aquatica. Indian J. Med. Sci. 2013; 67:49-60.

Mao L, Xu D, Yang J, Yuan F, Gao Y, Zhao J. Effects of Small and Large Molecule Emulsifiers on the Characteristics of b-Carotene Nanoemulsions Prepared by High Pressure Homogenization. Food Technol. Biotechnol. 2009; 9862:336-342.

Patel P, GM C, A A. Self Emulsifying Drug Delivery System. Res. J. Pharm. Technol. 2008; 1.

Rao SVR, Shao J. Self-nanoemulsifying drug delivery systems (SNEDDS) for oral delivery of protein drugs: I. Formulation development. Int. J. Pharm. 2008; 362:2-9.

Sabu MC, Kuttan R. Antidiabetic activity of selected medicinal plants and its possible mechanism of action Anti-diabetic activity of medicinal plants and its relationship with their antioxidant property. $\mathrm{J}$. Ethnopharmacol. 2014.

Shah P, Bhalodia D, Shelat P. Nanoemulsion: A pharmaceutical review. Syst. Rev. Pharm. 2010; 1:24.

Shukla JB, Patel SJ. Formulation And Evaluation Of Self Micro Emulsifying System Of Candesartan Cilexetil. Int. J. Pharm. Pharm. Sci. $2010 ; 2: 2-5$.

Sucharitha E, Estari M. Evaluation of antidiabetic activity of medicinal plant extracts used by tribal communities in rural areas of Warangal district, Andhra Pradesh, India. Biology and Medicine. Biol. Med. 2013; 5:20-25.

Uttara B, Singh AV, Zamboni P, Mahajan RT. Oxidative Stress and Neurodegenerative Diseases: A Review of Upstream and Downstream Antioxidant Therapeutic Options. Curr Neuropharmacol. 2009; 7:65-74.

Yen C, Chang C, Hsu M-C, Wu Y-T. Self-Nanoemulsifying Drug Delivery System for Resveratrol: Enhanced Oral Bioavailability and Reduced Physical Fatigue in Rats. Int. J. Mol. Sci. 2017; 18.

How to cite this article:

Jumaryatno P, Chabib L, Hayati F, Awaluddin R. Stability Study of Ipomoea reptans Extract Self-Nanoemulsifying Drug Delivery System (SNEDDS) as Anti-Diabetic Therapy. J App Pharm Sci, 2018; 8(09): 011-014. 